\title{
Erin Weber
}

\section{You can improve}

\section{Using the Framework in How to Read workshops}

$I^{\mathrm{n}}$ nformation literacy is inseparable from reading literacy, but neither are a basic or innate skill. Both take time, practice, repetition, and a host of willing instructors ready to engage in critical discussions about reading strategies. This is particularly true for firstgeneration, non-traditional, and marginalized students. ${ }^{1,2,3}$ Instruction librarians are uniquely positioned to promote and teach reading comprehension in a broader context of literacy, including information literacy.

In fall 2019, I hosted seven library workshops titled "How to Read Your Textbook" at the University of Tennessee-Martin, in which I provided students with broad techniques and specific tips to improve their reading comprehension. In addition to information literacy skills, several of the frames in the ACRL Framework for Information Literacy for Higher Education apply to reading skills as well. ${ }^{4}$

In each workshop, students learned about four suggested reading strategies: break it down, write it out, say it out loud, and connect it to your life. We discussed various ways to implement each of these reading strategies, and I encouraged students to share their own reading strategies with each other. These four strategies are neither new nor groundbreaking for those of us familiar with scholarly work, but many students have never heard these strategies explicitly stated. Librarians provide a roadmap for students unfamiliar with the complexities of research, information creation, academia, library jargon, and literacy.
Before creating this workshop, I talked with other librarians and professors on my campus, many of them frustrated and confused that students couldn't seem to comprehend their textbooks. I also attended a session at the ACRL 2019 Conference titled "Reading critically, thinking critically: Challenging assumptions about the role of reading in academic research." ${ }^{5}$ After this session, I began to think more about the ways that reading literacy is integral to our information literacy instruction.

Research has little value without action. It is not enough for students to find materials, they must also be able to use those materials, including critical reading. By viewing reading as an extension of the Framework, librarians and students can uncover new ways to examine the college-level reading process.

\section{Reading as Strategic Exploration}

There are several reasons why students don't read their assigned readings, but one of the biggest reasons is that they do not understand the material. ${ }^{6}$ While many professors take this as an opportunity to air their grievances about student deficiencies, students are more likely to improve their reading comprehension when they view literacy as a skill they can develop, ${ }^{7}$ particularly a skill that they are equipped to deal with as college students.

Erin Weber is information literacy librarian at University of Tennessee-Martin, email: eweber5@utm.edu

(C) 2021 Erin Weber 
Our time as educators is best spent sharing our reading techniques with students to give them confidence to practice literacy, rather than embarrassing students for what they do not know.

Reading, research, writing, critical thinking, and other forms of literacy are all malleable skills. As librarians, information professionals, and educators, we have a responsibility to demonstrate that malleability and improvement in our teaching philosophy. Readers can explore a document in strategic and careful ways. Different types of reading require different context and skills, and each one provides an avenue for student improvement. This frame allows librarians to examine different types of reading, including lateral reading for news articles and social media, multiple read-throughs focused on different sections for scholarly articles, and how to break down a long textbook chapter.

In the workshop, students discussed how to explore an article and read with heightened strategic awareness. By breaking down an article into manageable chunks, skimming, and reading out of order, students saw several options to strategically explore a document outside of the traditional, linear, "top-to-bottom" path. Students were most surprised to consider reading out of order, particularly reading the introduction and conclusion first. With these solid bookends in place, readers could then further explore the middle of the text.

Students were also shocked to learn that scholars and professors skim and read the sections of an article out of order. We discussed the many hours of reading professors had put in to get to a point where they understood when and how to effectively skim. For many students, the idea that they could skip to the end of an article and read the conclusion first was almost radical. Reading out of order is natural to scholars who work with these articles often, but students may not have ever seen it presented as an option. The students and I also discussed other ways to read out of order, including reading the easiest sections first, reading headings, looking for images or graphs first, or starting at the end of an article and working backwards.

With every technique, I emphasized that this one workshop is not a magic fix. True college-

\section{By viewing reading as an exten- sion of the Framework, librarians and students can uncover new ways to examine the college-level reading process.}

level literacy takes incredible amounts of time, effort, and critical engagement, but I hoped to give students multiple options to explore. I also wanted to show them that there is more than one correct way to read, understand, and engage with a text. Instead of erroneously assuming what students already know, librarians can break down the elements and order of reading to help students find the reading strategies that work best for them. By purposefully giving class space to explore reading techniques, we validate that there is more than one correct approach and we create a more inclusive classroom.

\section{Reading as Inquiry}

Research as Inquiry naturally connects to promoting and instructing student reading strategies. Readers interact with a document to answer questions and learn new information. With this frame, I encouraged students to always find a question to consider as they read. For many students, this involved finding the thesis statement or key argument for a section of text, but they could also consider questions from their own lives. Why does this topic matter? Will this demonstrate what I think I already know? Where have I heard this idea before? Reading discipline-specific texts is an iterative process, where students uncover new questions to ask each time they read a document.

I encouraged students to spend a few minutes thinking about a text before they started reading. Look for a question that the reader should want to answer, even if it was something as simple as "Why does this work matter?" or "What is the author's point?" I asked students to keep that question in mind for every paragraph, image, heading, and discussion question.

I also encouraged students to consider their own best practices, particularly around note- 
taking. Reading and writing are inextricably linked, and notetaking remains one of the best tools to promote reading comprehension. However, student notetaking abilities vary, and the quality of the notes effects how well students comprehend and retain their readings. ${ }^{8}$ In particular, students often overuse highlighters and rely on highlighted sections to improve their reading comprehensions, rather than understanding which sections to highlight in the first place. ${ }^{9}$

In the workshop, we discussed how notetaking and highlighting can be useful tools, but they are most effective when used critically and carefully. Students were encouraged to see notetaking as a way to answer the questions that the author or reader should want to know. Instead of highlighting or underlining as you read, spend some time describing the text after you finish a section. What is the thesis statement or key point? What was the text about, and why does it matter? What are the most important takeaways? How does this connect to other material covered in class, How does it connect to what you already know about this topic? Students might also take notes on anything they were confused about or needed to do more research on, further connecting with Research as Inquiry.

\section{Reading as Conversation}

While reading is generally considered a solitary activity, it is beneficial for students to see reading as a conversation. Writers do not create in a vacuum. They draw on scholarship and ideas from other readings and their own lived experience. Likewise, readers do not read in a vacuum. Students converse with both the document itself and the people around them to deepen their understanding. As libraries continue to shift to more collaborative spaces, ${ }^{10}$ perhaps a shift is necessary towards a more collaborative approach to literacy.

Students were encouraged to discuss reading strategies and their textbook readings during this workshop, deepening their understanding of reading through a literal scholarly conversation. Students also participated in a conversation with the document itself by finding ways to connect it to their life. I asked students to ask questions, share what they did not understand, what they did or did not agree with, where they had heard these concepts before, and why readers should care. Although students were most easily able to converse with material in the humanities, particularly historical events that they had heard about from family members, they were able to start a reading conversation in most disciplines.

One of the workshop strategies was for students to "say it aloud." This strategy included reading aloud in a study group, discussing readings with classmates, verbalizing questions, and summarizing the key points to another person. I intentionally shared with students my own conversations about creating the workshop itself. I used scholarly material and discussion with other professors on my campus to create the How to Read Workshops, embodying the value in Scholarship as Conversation.

\section{Conclusion}

For professors, educators, librarians, and students, it is imperative that we see reading as a skill we all should practice and improve. Because of its flexible and interlocking nature that connects every stage of the research process, the ACRL Framework allows us to demonstrate tangible strategies to improve literacy and reading comprehension. As scholars and educators, the intricacies of scholarship become second nature to us. However, for many first-generation and marginalized students, college-level research is like a foreign language, complete with unspoken rules and cultural expectations.

Part of our work as librarians is to demystify what academics "do." We cut through the jargon to provide clear, accessible, useful examples and explanations about literacy and information. It is not that students cannot read critically or research effectively, it's that they have never been explicitly taught how to do so in a college context.

Reading instruction is already an implicit part of our curriculum because of a shared assumption that in order to evaluate, find, use, and create new information, scholars must first read information. However, reading is rarely 
stated as a specific goal in information literacy instruction. Librarians have a valuable role to play in building student confidence and demonstrating strategies to improve college-level reading. What may be an obvious purpose or benefit to us is rarely so obvious for students.

While librarians will not vastly improve student reading comprehension in one library literacy instruction session, there is indescribable value in giving students the confidence to practice literacy. Instead of a chore, I want students to see reading as a valuable skill that they can improve, and I want to prove that it is valuable by giving it dedicated instruction time. The Framework helps us provide students with skills to value and practice reading comprehension.

Reading is strategic exploration, so what are the ways that we can make it more strategic? How can we explore these documents in new ways? Reading is inquiry, so let's enquire about every question and section. Reading is a conversation, and we can shift it to a more collaborative discussion between students and in the classroom. Above all, reading is an information literacy skill.

\section{Notes}

1. Juliet Michelson Wahleithner, "The High School-College Disconnect: Examining FirstGeneration College Students' Perceptions of Their Literacy Preparation," Journal of Adolescent and Adult Literacy 64 no. 1 (2021): 19-26, https:// doi.org/10.1002/jaal.1057.

2. Krista M Malott, Stacey Havlik, Shivam Gosai, Jose Diaz Davila, and Sam Steen, "College Readiness and First-Generation College Goers: Group Impacts with Students from an Urban, Predominantly African-American Population," Journal of Child \& Adolescent Counseling 5 no. 3 (2019): 256-74, https://doi.org/10.1080/23727 810.2019 .1672241 .

3. Chuck Wilkins, Eric Rolfhus, Jenifer Hartman, Sarah Brasiel, Jessica Brite, and Noelle Howland, "How Prepared Are Subgroups of Texas Students for College-Level Reading: Applying a Lexile-Based Approach (REL Technical Brief, REL 2012- No.018)," Washington, D.C.: US Department of Education, Institute of Educa- tion Sciences, National Center for Education Evaluation and Regional Assistance, Regional Educational Laboratory Southwest, http://ies. ed.gov/ncee/edlabs.

4. "Framework for Information Literacy for Higher Education," (Chicago: ACRL, 2015).

5. Anne-Marie Deitering, Hannah Gascho Rempel, Anne Jumonville Graf, Ashleigh Coren, and Stephanie Otis, "Reading critically, thinking critically: Challenging assumptions about the role of reading in academic research," presentation at the ACRL 2019 Conference, Cleveland, OH, April 10-13, 2019, http://www.ala.org/acrl/sites/ala.org.acrl /files/content/conferences/confsandpreconfs/2019 /acrl2019_program.pdf.

6. Keith Starcher and Dennis Proffitt, "Encouraging Students to Read: What Professors Are (and Aren't) Doing about It," International Journal of Teaching and Learning in Higher Education 23 no. 3 (2011): 396-407, https://files.eric.ed.gov/fulltext /EJ946166.pdf.

7. Elizabeth A. Gunderson, Noora Hamdan, Nicole S. Sorhagen, and Alexander P. D'Esterre, "Who Needs Innate Ability to Succeed in Math and Literacy? Academic-Domain-Specific Theories of Intelligence about Peers Versus Adults," Developmental Psychology 53 no. 6 (2017): 11881205, http://dx.doi.org/10.1037/dev0000282.

8. Kayla Morehead, John Dunlosky, Katherine A. Rawson, Rachael Blasiman, and R. Benjamin Hollis, "Note-Taking Habits of 21st Century College Students: Implications for Student Learning, Memory, and Achievement," Memory 27 no. 6 (2019): 807-819, https://doi. org/10.1080/09658211.2019.1569694.

9. Vicki Silvers Gier, David S. Kreiner, and Amelia Natz-Gonzalez, "Harmful Effects of Preexisting Inappropriate Highlighting on Reading Comprehension and Metacognitive Accuracy," Journal of General Psychology 136 no. 3 (2009): 287-300.

10. Daejin Kim, Sheila Bosch, and Jae Hwa Lee, "Alone with Others: Understanding Physical Environmental Needs of Students within an Academic Library Setting," The Journal of Academic Librarianship 46 no. 2 (2020), https://doi. org/10.1016/j.acalib.2019.102098. z 